\title{
Utilization of IoT for Soil Moisture and Temperature Monitoring System for Onion Growth
}

\author{
Izak Habel Wayangkau ${ }^{1}$, Yosehi Mekiuw ${ }^{2}$, Rachmat Rachmat ${ }^{1}$, \\ Suwarjono Suwarjono ${ }^{1}$, Hariyanto Hariyanto ${ }^{1 *}$ \\ ${ }^{a}$ Faculty of Engineering, Universitas Musamus, Merauke 99600, Papua, Indonesia \\ ${ }^{b}$ Faculty of Agricultural, Universitas Musamus, Merauke 99600, Papua, Indonesia
}

\begin{abstract}
The use of IoT in precision agriculture is very important in the process of increasing crop production. The local supply of onions in Merauke Regency have not fulfilled the demand, thus the high price in the market. Most of the demand for onion are still fulfilled from outside the region, as the production of local farmers has not been optimal. The weather has been identified as one of the factors that affect the quality of onion production. This study aims to create an automatic monitoring system based on an Arduino microcontroller to measure soil moisture and temperature in onion patches. The method used is to design an automatic monitoring device to determine soil moisture and temperature so that it can provide information about the growth and maintenance of onion patches. The Arduino microcontroller is connected to a reading sensor that is integrated with component devices to maintain a stable temperature and soil moisture. All devices and components are designed to operate in a custom-made environment in the form of a greenhouse prototype. The results of this study indicate that the tool and system are capable of capturing the soil moisture and temperature, as well as maintaining the soil moisture and temperature within certain parameters, in cloudy, wet and hot weather conditions.
\end{abstract}

Keywords:

Internet of Things (IoT);

Monitoring System;

Agriculture;

Microcontroller;

Android.

\section{Article History:}

Received: 19 June 2021

Revised: 23 September 2021

Accepted: 02 October 2021

Published: 19 October 2021

\section{1- Introduction}

Merauke Regency is located between 137'-141' East and 5'-9' South, geographically located at the southern part of the easternmost part of Indonesia, with an area of 46,791.63 $\mathrm{km}^{2}$ [1]. Merauke Regency is known as the largest regency in Papua Province, and is also a leader in the production of three important food crops, with a total production of around $91.47 \%[2,3]$. The area's low-lying topography and land elevation are highly suitable for the development of agriculture and plantations. The huge agricultural potential gave rise to the idea of making Merauke Regency one of the world's food barns, known as the Merauke Integrated Food and Energy Estate (MIFEE) concept [4-6]. The total area of available agricultural land reaches 1.2 million ha, with 800,000 ha that has the potential for food crop development, and currently, only about $13 \%$ is managed using modern methods. The annual production of food crop commodities that have been successfully developed includes 327,877 tons of rice; 8,556 tons of corn; 4,627 tons of cassava; 592 tons of peanuts and 90 tons of green beans. However, one type of food crop commodity has not been fully developed, namely onions [7], where the amount of production is very low. The demand for onions in Merauke Regency is still fulfilled by other regions, the largest onion suppliers for the Papua region being the provinces of East Java, West Sumatra, and West Nusa Tenggara. The lengthy supply chains are at risk of delays in delivery and constraints in terms of transportation and other obstacles, such as weather and natural conditions that do not allow delivery, causing a lack of availability of onions. The high demand for onions, limited availability, and high prices require a breakthrough and innovation in the development of onion crops through optimal cultivation techniques.

\footnotetext{
*CONTACT: hariyanto_ft@unmus.ac.id

DOI: http://dx.doi.org/10.28991/esj-2021-SP1-07
}

(C) 2020 by the authors. Licensee ESJ, Italy. This is an open access article under the terms and conditions of the Creative Commons Attribution (CC-BY) license (https://creativecommons.org/licenses/by/4.0/). 
In 2018 Kelyum et al. [8] has conducted research on the development of onion cultivation in Merauke Regency, finding that several factors that cause very low production yields are planting media, weather, and maintenance. Meanwhile, the results of direct interviews that we conducted in July-August 2020, with several onion farmers in Merauke Regency also showed that there were five problems faced by onion farmers including: 1 . lack of knowledge about cultivation techniques; 2 . poor soil conditions for planting onions; 3 . changes in the weather in the field; 4 . appropriate volume of water for onion plants; 5. maintaining stable temperature and humidity in the onion cultivation areas.

The onion is a horticultural plant with the Latin name of Allium ascalonicum L., usually used as a main condiment, and can also be used as a basic ingredient for medicines that are highly beneficial for the body [9, 10]. The development and growth of onion plants are strongly influenced by the availability and sufficiency of water, application of fertilizer, and the right weather [11-14]. To provide solutions to overcome these challenges, the Internet of Things (IoT) systems are becoming more relevant, where many researchers in the world [15-17] have utilized IoT to optimize plant growth and production. Various sensors can be used and connected to build a soil moisture and temperature monitoring system in the rainy and hot seasons so that plants continue to get nutrients to grow and develop [18, 19]. In 2019 Rahmat et al. [20] have conducted research to monitor the growth of onions using the hydroponic method, but the resulting system can only display data on agricultural land area and is not connected to the Android application on mobile phones. Kaburuan et al. [21] has also conducted research by building a greenhouse design to monitor the growth of crops. The results of his research also show data such as soil, water, and air conditions that can be seen in detail. However, in this study, the system that has been built cannot be controlled remotely. The latest research in 2021, conducted by Khan et al. [22], made a new prototype, namely the Smart Farming Monitoring System (SFMS) to reduce bolting on onion crops in the Khyber Pakhtunkhwa district of Pakistan, however in this study only one climatic and weather conditions were presented due to demographic factors. Demographic factors greatly affect the effectiveness of the system that is built and developed. Meanwhile, Indonesia has a tropical climate, and in Merauke Regency, there are 3 seasons, namely cloudy, rainy, and hot.

Therefore, innovative actions are needed that can solve the problems of farmers in an effort to cultivate onion plants by utilizing IoT that can be controlled remotely. This study aims to create an automatic monitoring system based on an Arduino microcontroller to measure soil moisture and temperature in onion plants. The method used is the design of an automatic monitoring device to determine soil moisture and temperature so that it can provide information about the growth and maintenance of onion plants. The Arduino microcontroller is connected to a reading sensor which is integrated with the Android operating system to be implemented in a greenhouse. This method adopts an artificial intelligence design by utilizing the advantages of the Nodemcu ESP 8266 microcontroller, as the input and output media of the research process to be achieved and Android as a medium for information on changes in conditions in the onion planting media in real-time. Then test the monitoring system and sensor readings on 3 weather conditions, namely when it is cloudy, rainy, and hot, system testing is carried out to measure the effectiveness of the system that has been made.

This research is expected to contribute greatly to science, namely by providing information about the use of IoT technology in precision agriculture, especially the growth of onion plants. The results of this study have a great impact on local farmers, namely being able to understand the composition of the best climate for the growth of onions and educating farmers to be able to use technology in agriculture. The structure of this article begins with an introduction, research motivation, and problems found in section 1 . Then section 2 contains an explanation of the materials and methods. This subsection will explain the maintenance and monitoring of onion growth, the manufacture of greenhouses, then the components needed to build a monitoring system for soil moisture and temperature. This system design was developed using the waterfall method, Use case Diagrams, Sequence Diagrams, and block diagrams are integrated based on Android. Furthermore, in section 3 the results of the discussion present the design view of the monitoring system that has been made, then graphs and tables show the effectiveness of the system. The last section concludes the results found and the future development of the application.

\section{2- Materials and Method}

\section{2-1-Onion Plant Maintenance and Monitoring}

In monitoring, data are collected, collated, processed and analyzed to obtain information about the implementation of a program or prototype, to easily find out whether the program is running well or not. Maintenance is an important element in the cycle of plant cultivation. Well-planned and well-maintained treatment will give optimal results [23]. In essence, maintenance is an effort to help plants grow and protect them from pests and diseases. Onion maintenance include the following main activities:

- Watering: onion plants need just enough water for growth. Lack of water in the vegetative growth phase causes the onion plants to grow stunted, on the other hand, excess water during tuber formation can cause tubers to rot, or crop failure due to the plant becoming damaged and rotten. Therefore, the provision of water must be sufficient for vegetative growth (young plants), soil conditions must be kept moist, so that watering is carried out 
continuously. For example, the plant must be watered twice a day, especially in the dry season. The critical time for the onion plant is rapid vegetative growth and the formation of leaves and bulbs. Research results showed that the amount of water needed for watering is $200 \mathrm{ml}$ every 2 days during the vegetative growth period. Onion plants need an air temperature of $31-32^{\circ} \mathrm{C}$, relative humidity of $50-60 \%$, and a minimum of $70 \%$ sunlight.

- Weeding: Weeds that grow next to onion plants will compete for space, light, and nutrients, and can even become OPT hosts, especially caterpillars. When weeds are cleaned up, onion caterpillar eggs are removed as well, and this activity is often done on the 2nd weeding. Generally weeding is done 1-2 times before the second application of fertilizer, at around 1 month. The critical period of onion plants due to competition with weeds occurs at the age of 30-60 days after planting. Weeding can be done manually, conventionally, and chemically, or a combination of the three.

- Fertilization: onion plants need to be fertilized in order to meet the needs of sufficient and appropriate nutrients for their growth to produce onion bulbs optimally. Nutrients are optimally available in the soil and can be utilized by onion plants through the use of fertilizers. Inorganic fertilizers are used, for example urea, TSP, KCL, or NPK, aiming to provide optimal nutrients in the soil needed by onion plants. The following example shows the fertilizing pattern in a monoculture system without plastic mulch as follows:

○ The type and dose of artificial fertilizer given consists of urea $100 \mathrm{~kg}-150 \mathrm{~kg}+\mathrm{ZA} 30 \mathrm{~kg}-400 \mathrm{~kg}+$ TSP $100 \mathrm{~kg}-150 \mathrm{~kg}+\mathrm{KCL} 150 \mathrm{~kg}-200 \mathrm{~kg}$ per hectare.

○ The timing and proportion of fertilizer application is set in stages as follows:

a) The first fertilization is given before planting onion seeds. The type of fertilizer used is NPK pellets (16:16:16) $500 \mathrm{~kg}$, SP36 as much as 50-100 kg, and KCI 30-60 kg for a hectare.

b) Urea, ZA, and $\mathrm{KCl}$ fertilizers were applied as supplementary fertilizers at 3, 6, and 9 weeks after planting the onions, each one-third the dose. This is intended for the growth of the bulbs because at the age of 15-30 days after planting, the nutrient reserves of the bulbs run out quickly, so $\mathrm{S}$ and $\mathrm{N}$ are needed for the manufacture of leaves and bulbs.

c) The second supplementary fertilizer is given to plants aged 30-35 DAP with $180 \mathrm{~kg} / \mathrm{ha}$ urea fertilizer. At that age, the plant begins to enter the phase of bulb formation, so it requires carbohydrates from photosynthesis as a bulb forming material.

d) Fertilization of onion plants does not need to be equal in each area, depending on the fertility of the soil. For this reason, information is needed that can help farmers to determine a balanced composition of fertilizers in the onion farming process.

\section{2-2-Greenhouse}

Onions grow in the lowlands to an altitude of about 100 meters above sea level. Optimal production results are achieved in the lowlands with a temperature of $25-32^{\circ} \mathrm{C}, 75 \%$ irradiation, and air humidity in the range of $50-70 \%$ with the provision of loose, fertile soil and lots of organic matter content. Such a condition can be maintained in a greenhouse. A greenhouse's size depends on how many plants are in it [24, 25]. In principle, the greenhouse functions to reduce the rapid flow of heat out of the building by blocking the heat that has been absorbed through convection. The construction material for these greenhouses is usually plastic/glass so that sunlight can pass through. It is important to allow sunlight to keep the greenhouse warm, because sunlight can heat the soil inside the greenhouse, which in turn warms the air in the greenhouse and then the plants in the greenhouse. This means that in a greenhouse, sunlight easily enters the building, but heat is retained inside the building.
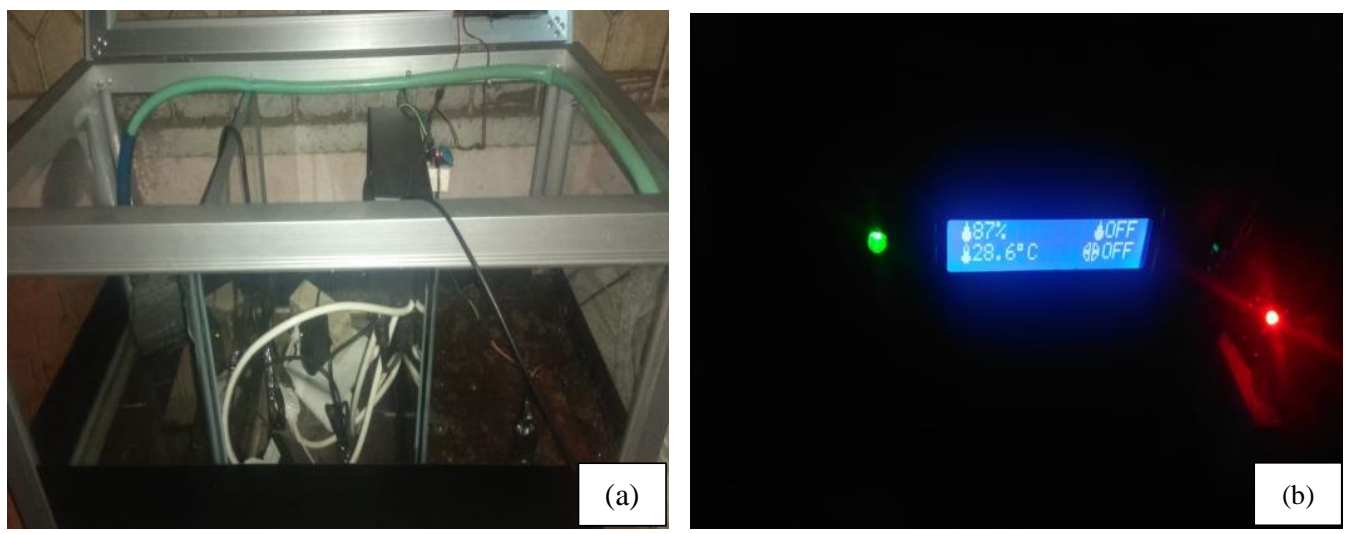

Figure 1. (a) Installation of Design Monitoring System; (b) Greenhouse display before sending to android. 
Figure 10(a) shows the results of the prototype design for the onion monitoring system and Figure 10(b) shows the appearance of soil moisture and temperature monitor during the rainy and hot seasons.

\section{2-3-Android}

The Android is a Linux-based mobile phone operating system, used on a tablet, computer or smartphone. Android is also an open source program so developers can create apps usable on multiple smart devices. The Android application on the plant monitoring system is considered very effective and efficient [26, 27] to assist users in maintaining ornamental plants remotely. The user can perform monitoring functions such as displaying information to the user about the growing conditions of the plant.

\section{2-4-Arduino Software (IDE)}

Programs written using Arduino Software (IDE) are called sketches. The sketch is written in a text editor and saved in a file with the extension .ino. The text editor on the Arduino Software has features such as cutting/pasting and searching/replace, making it easier to write program code [28]. In the Arduino IDE Software, there is a kind of black message box that serves to display status, such as error messages, compile, and upload programs. The bottom right of the Arduino IDE Software shows the board configured along with the COM Port in use.

\section{2-5- Unified Modeling Language (UML)}

UML is the first modeling language used to analyze, define and design software systems as an object-oriented programming language that is beginning to be used in the software industry, as the name implies. Unified modeling language (UML) describe the activities that occur in the system, from start to finish. Unified Modeling Language (UML) can show the steps in the work process of the system that we will build.

\section{2-6-Sensor Monitoring}

- Capacitive soil moisture sensor v2.0: Capacitive soil moisture sensor v2.0 is a sensor that can read the intensity of the water content in the soil (moisture). This sensor uses two conductors to pass current through the ground, then reads the resistance value to obtain a reading of the humidity level. Using this wireless sensor, farmers can remotely measure soil moisture because the data from the soil moisture sensor V2 SEN0114 will be sent wirelessly by the nRF24L01+ transceiver module to the LCD at the base station location. The sensor's specifications are as follows: 1. Working current $35 \mathrm{~mA} ; 2$. Input voltage 3.3 or $5 \mathrm{~V}$ and output voltage is $0 \sim 4.2 \mathrm{~V} ; 3$. Value range 0-300 (dry soil), 300-700 (moist soil), and 700-950 (wet soil).

- DHT 11 Sensor: The DHT 11 sensor is a single chip humidity and temperature sensor whose output is digitally calibrated. The inside of this sensor contains a polymer element to measure relative humidity and a stretch band used to measure temperature. The outputs of the two sensors are combined with a 14 bit ADC.

- NodeMCU ESP8266: NodeMCU is an open source IoT platform. NodeMCU firmware runs on the ESP8266 WiFi SoC designed by Espressif Systems which is based on the ESP 12 Module. The term NodeMCU by default refers to the DevKit firmware. The firmware uses the Lua scripting language and can be used in several projects such as luacjson, and spiff.

\section{2-7- Waterfall Methods}

The method used for the development of the system is the waterfall method because the stages that are passed must wait for the completion of the previous stages and run sequentially [29]. Presman, R. S. divides this model into 6 stages, namely:

- Information Systems and Engineering: At this stage, the authors look for the needs of the entire system that will be applied to the software. These needs are obtained from the process of observation, interviews, and through the process of literature study.

- Software Requirements Analysis: After carrying out the first stage and then analyzing it, the next stage will be intensified and focused on software development and then interface designing.

- Design: At this stage, the needs that have been analyzed are converted into representations in the form of a blueprint for the system to be built with the design stages starting from Activity Diagrams, Use Cases, Flowcharts, and Sequence Diagrams.

- Coding: This is the stage of writing programming language code to produce a script that is run on a computer machine. The coding here is built with two different programming language stages, namely Android Studio to build a system interface, and Arduino IDE as a means to enter code into the Arduino Uno prototype board to run a series of devices that have been built. 
- Testing/Verification: Performing functional testing and logical correctness of the system built with the aim of finding out whether there are errors or not, knowing whether the system made is in accordance with the initial design or not, and knowing the shortcomings of the system that has been designed/made.

- Maintenance: This stage is carried out by maintaining software and hardware that has changed because the software created and sent to users does not rule out changes. This change may occur due to an error that appeared and was not detected during testing.

\section{2-8-Use Case Diagram}

Use Case is a model to perform the information system (behavior) to be created. Use Case describes an interaction between one or more information systems to be created [30, 31]. Use Cases are used to find out what functions exist in an information system and who has the right to use these functions.

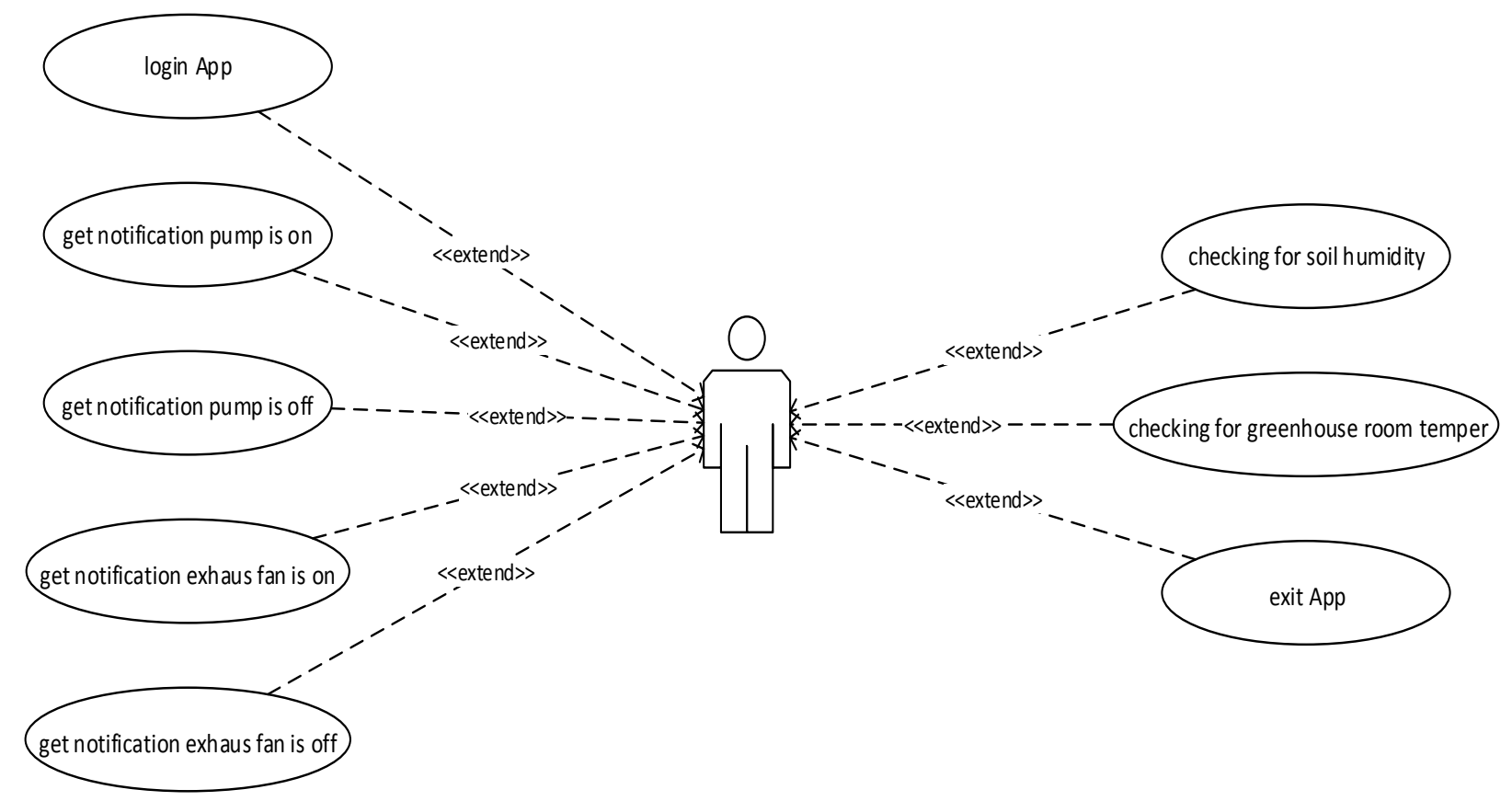

Figure 2. Use Case Diagram.

As shown in Figure 2, the Use Case Diagram is described: 1. The use of the system consists of Farmers (Users); 2. Users use the tool as a medium for monitoring watering and controlling the room temperature of the greenhouse on onion plants; 3. Farmers connect Android with NodeMCU ESP8266, to find out the latest soil and air humidity on onion growing media.

\section{2-9- Watering Sequence Diagrams}

Sequence diagrams describe the behavior of objects contained in the use case by translating the lifetime of objects and messages sent and received between objects.

Figure 3 is a Watering Sequence Diagram that describes the process that occurs when farmers monitor humidity through an Android smartphone sensor to detect soil conditions, farmers get soil moisture information. Then the sensor will detect soil moisture if the humidity is less than the specified number, the water pump will turn on and wet the soil surface on the onion plant to the specified humidity limit, the pump will turn off and the farmer will get a notification that the soil moisture is sufficient. 


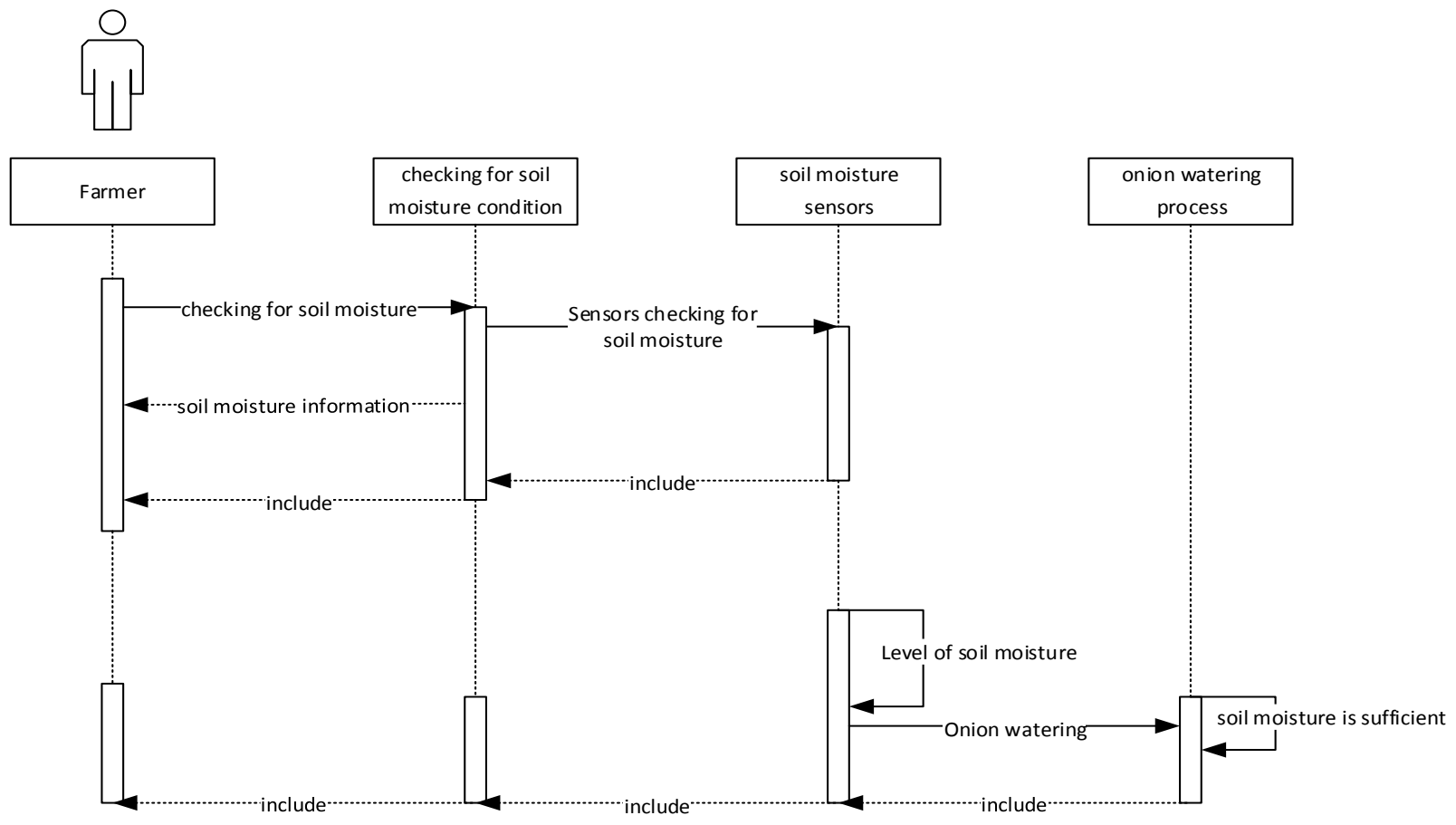

Figure 3. Watering Sequence Diagram.

Figure 4 shows the Sequence Diagram of air temperature control that describes the process that occurs when farmers monitor humidity through Android smartphone sensors detecting temperature conditions, farmers get air humidity information. The sensor will detect the room temperature, if the room temperature is higher than the specified limit then the climate control mechanism is activated to keep the temperature at a predetermined limit. Furthermore, the climate control will be turned off after the temperature is at a predetermined limit, and farmers will get a notification that the room temperature has stabilized.

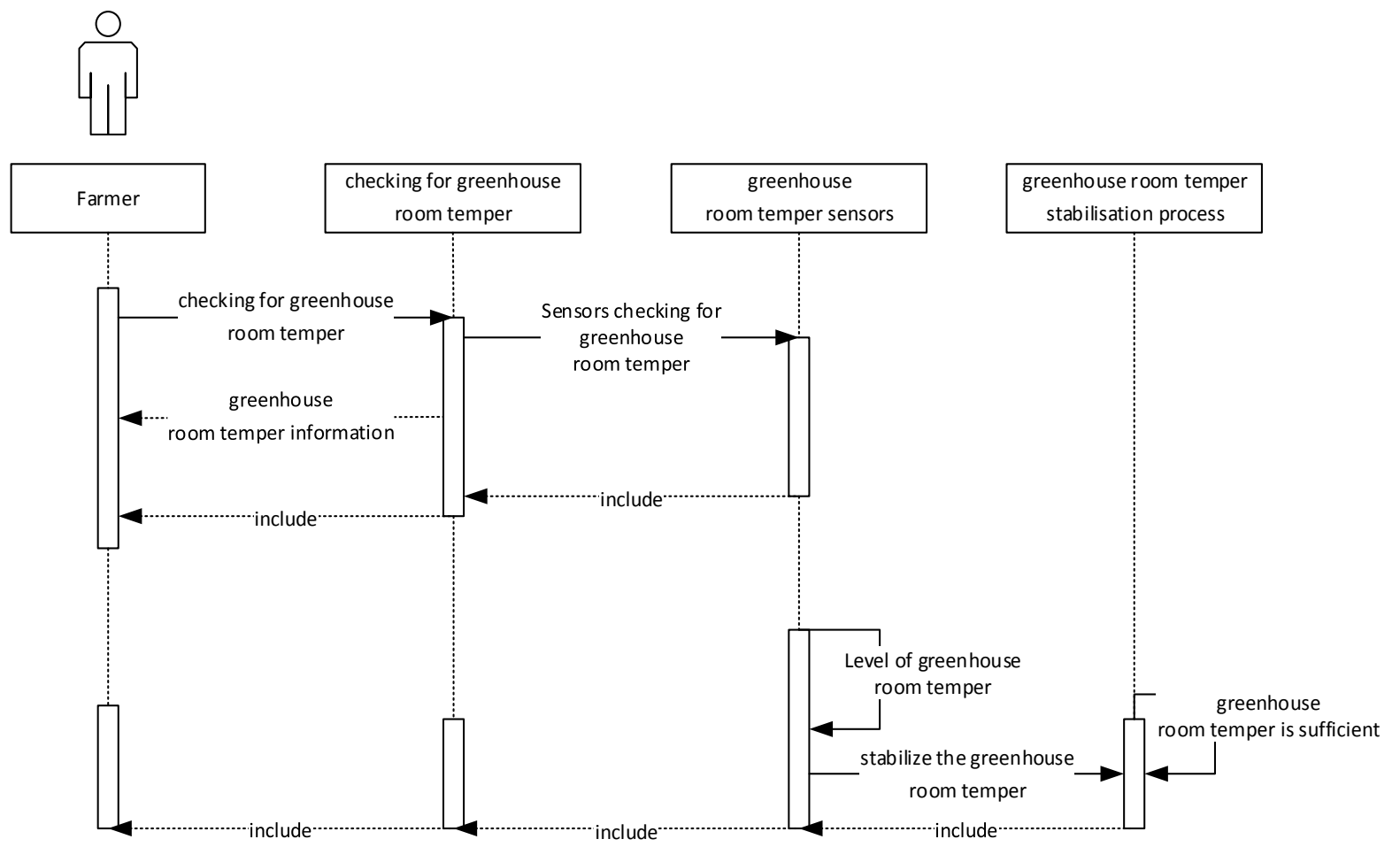

Figure 4. Sequence Diagram of onion temperature control.

The proposed system in the research that will be built to be a solution to the problems for onion farmers in the planting and watering process is the onion plant growth monitoring system using the NodeMCU ESP8266 microcontroller. The proposed flow can be seen in the flowchart, among others: 


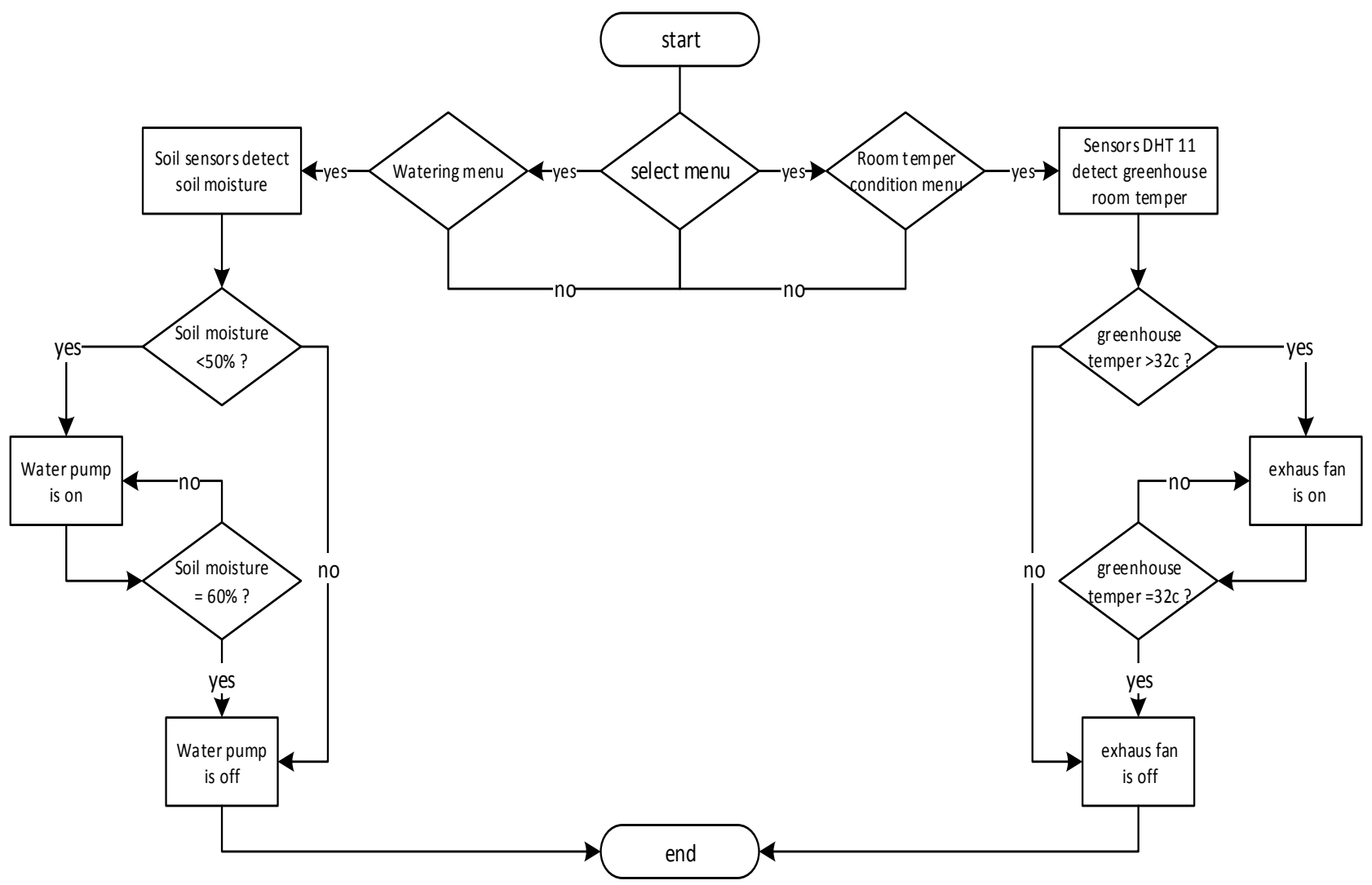

Figure 5. Flowchart of the proposed system.

Based on Figure 5, the proposed system is described as follows: The initial process of the Android smartphone initializes the sensor, then the Android connects to the NodeMCU ESP8266. If it fails then the process is repeated until it is connected, the soil moisture sensor is active and sends moisture information to Android. If the soil moisture is less than 50\% then the Android application will automatically send commands to the NodeMCU ESP 8266 to activate the water pump until the soil moisture meets the plant's needs or equal to $60 \%$ then the NodeMCU ESP8266 automatically deactivates the pump and sends a notification to Android that the soil moisture is sufficient. A similar process occurs on the air temperature menu. When the air temperature sensor on the NodeMCU ESP8266 system is active, it automatically detects the value of the air temperature in the greenhouse and sends the information to Android. If the air temperature is more than $32^{\circ} \mathrm{C}$ then Android sends a command to the NodeMCU ESP 8266 to turn on the fan, then after the temperature drops to $31^{\circ} \mathrm{C}$ NodeMCU ESP8266 turns off the fan and sends a notification to Android that the temperature has stabilized.

Diagrams are made to map the working process of the tool being built. It aims to recognize the required hardware and also be able to understand the prototype workflow. Figure 6 is the Prototype Block Diagram consisting of several components that will be used to build the onion monitoring system including Android, soil moisture sensor, air temperature sensor, NodeMCU ESP8266, database, power source, Arduino LCD, dual relay on Arduino, 12-volt water pump and 12-volt greenhouse cooling fan.

\section{3- Results and Discussion}

The tool was tested in 3 different weather conditions, namely 1. Cloudy weather, 2. Rainy weather, and 3. Hot weather. The three weather conditions represent the tropical climate, with three seasons applicable to Merauke Regency. The monitoring is carried out in several occurrences in the morning until the afternoon, namely at 07.00, 09.00, 11.00, 15.00 , and 17.00, during which time onion plants need more nutrients (water) than in the evening. With regard to soil moisture, the tool will water the soil if the soil moisture content falls below $50 \%$, and the tool will stop watering the soil when the soil moisture content reaches the level of $60 \%$ or more. With regard to room temperature, the tool will activate the air conditioning fan if the room temperature exceeds $32^{\circ} \mathrm{C}$, and the tool will turn off the air conditioning fan if the temperature is at $31^{\circ} \mathrm{C}$ or below. 


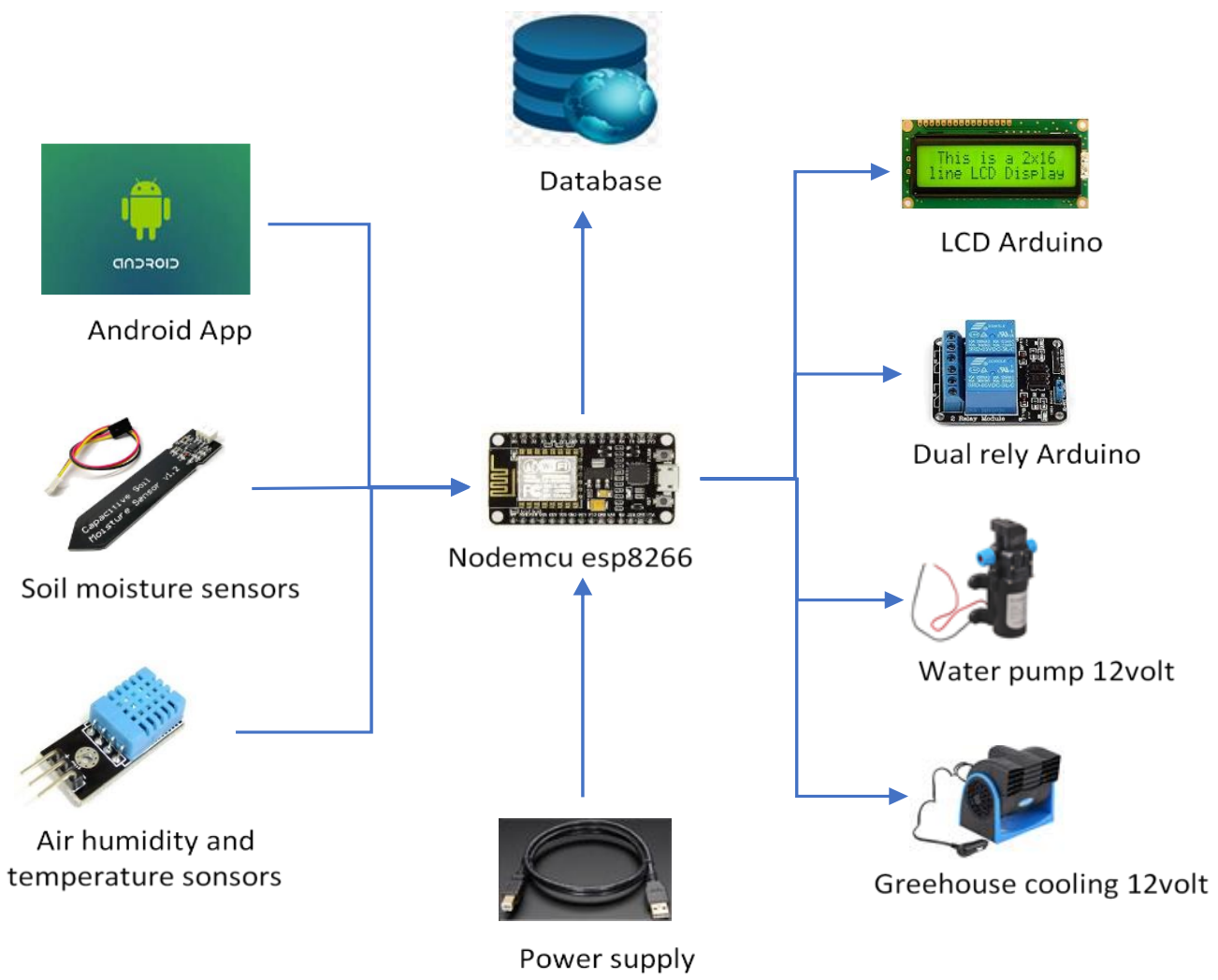

Figure 6. Block Diagram Prototype.

\section{3-1-Monitoring Form}

Figure 7(a) shows the results of the monitoring form display on the Android application. When the user opens the application, the user is served this page, and receive information on the status of the water pump ON or OFF and the status of the greenhouse fan ON or OFF. In this monitoring application users will also get sensor data that provide information about the state of soil moisture, and room temperature. Figure 7(b) shows the results of displaying data and graphics on the Android application, users receiving the latest information about the state of soil moisture and air temperature on the onion growing media. If the soil moisture sensor detects soil moisture to be less than $50 \%$, the pump is turned ON (watering) and if the value is equal to $60 \%$ then the pump is turned OFF. Similarly, if the DHT 11 detects the room temperature to equal $31^{\circ} \mathrm{C}$ then the fan will be OFF (controlling temperature) and if it is more than $32^{\circ} \mathrm{C}$ then the fan is turned $\mathrm{ON}$. These processes automatically send notifications to the app user.

\section{3-2-Overall Test Results of Tools and Systems}

Overall tool testing includes hardware and software testing. The test is carried out by sending the soil moisture value, measured using the soil moisture sensor and sending the room temperature humidity value with the humidity sensor to the NodeMCU ESP8266, which then compares the data to the database using the SIM8266 module and sending the results to an Android smartphone in the form of notifications and data on soil moisture and greenhouse room temperature. Tables 1, 3, and 5 show the results of testing of maintaining the soil moisture, while Tables 2, 4, and 6 show the results of testing of maintaining the room temperature.

\section{3-3- Watering and Temperature Control Testing During Cloudy Weather}

The test results on monitoring soil moisture in cloudy weather conditions are shown in graph (a) showing the ability of the tool to respond to changes in soil moisture content, seen at 09.00 when the soil moisture level decreased below the limit, the system responded by activating the soil moisture procedure by adding supply of water into the soil so that the percentage of soil moisture increases. As seen in the graph, the percentage of soil moisture has increased again and is maintained until 17.00. The soil moisture is kept high, partially by the cloudy weather. The test results on monitoring the greenhouse room temperature in cloudy weather conditions are shown in graph (b), appearing that the system does not activate the room temperature cooling process because the room temperature continues to remain below the minimum limit until 17.00. This condition is also influenced by the cloudy weather condition at the time of testing. From the test results shown in Tables 1 and 2, it can be concluded that when the weather is cloudy the tool and system captures soil moisture above $60 \%$ and the DHT 11 sensor captures humidity in the room temperature range of $28^{\circ} \mathrm{C}$. 


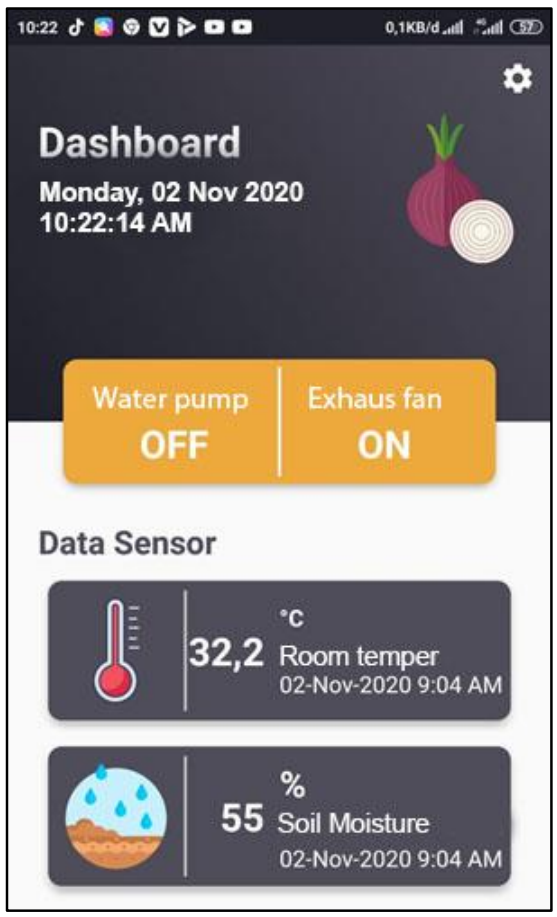

(a)

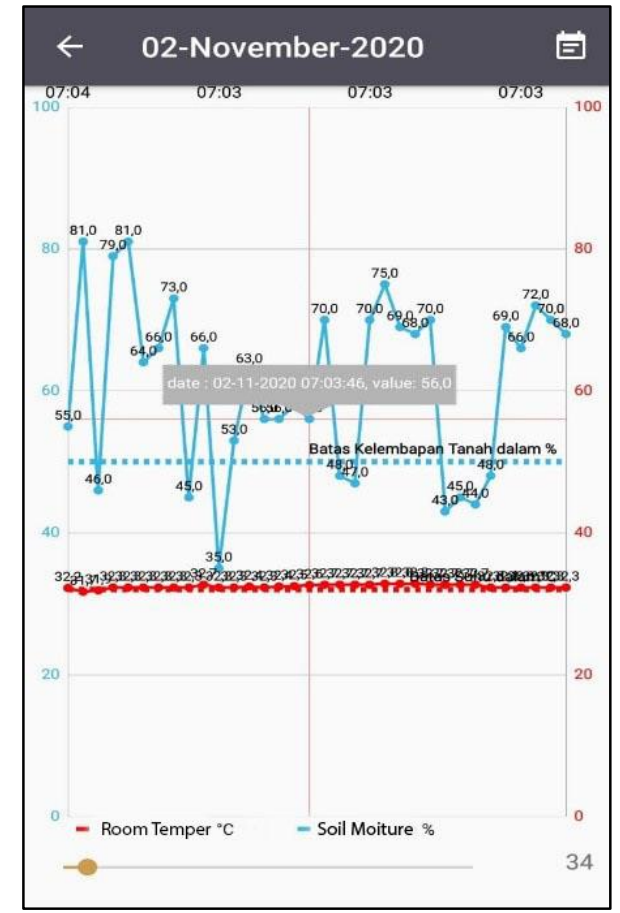

(b)

Figure 7. (a) Monitoring page in Android; (b) Graphic data page in Android.

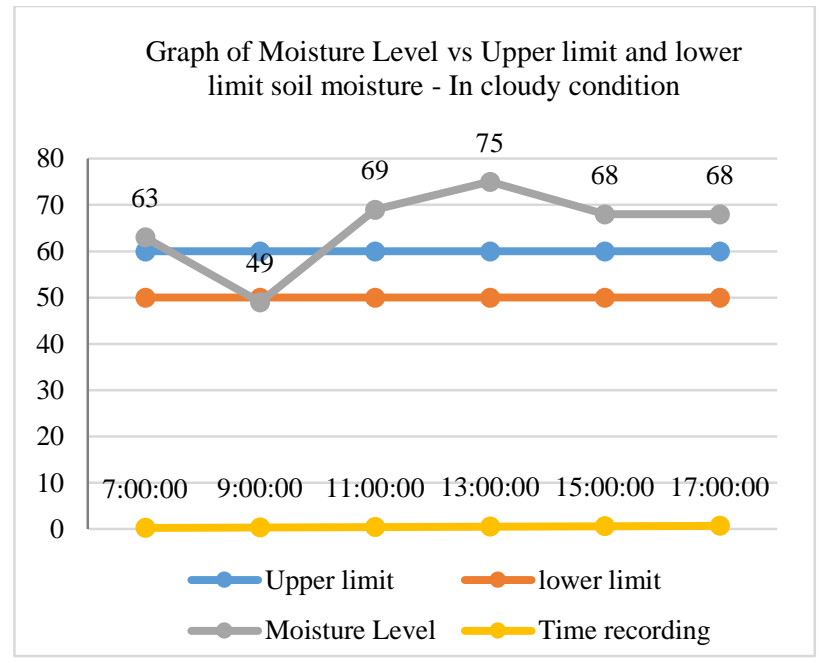

(a)

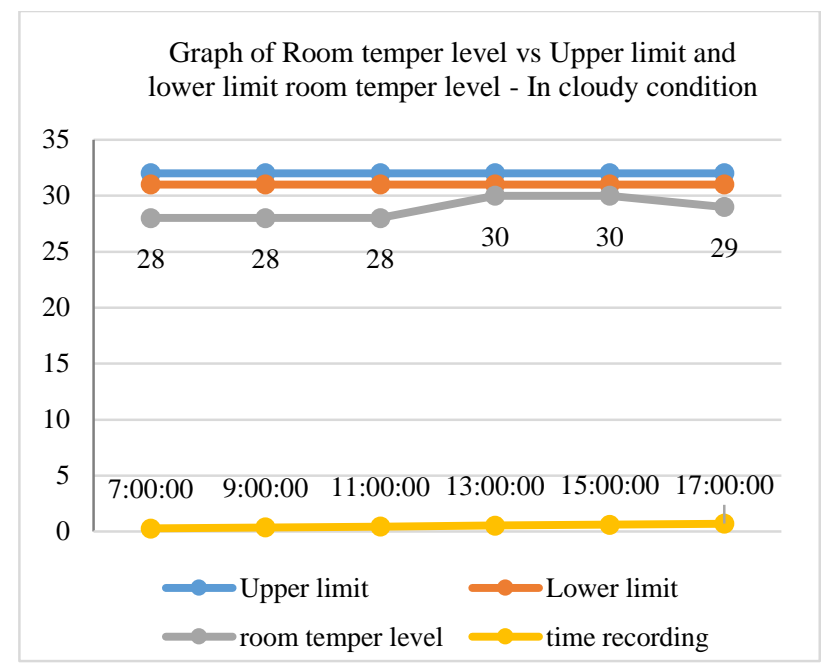

(b)

Figure 8. (a) Graph of Moisture Level; (b) Graph of Room temperature level.

Table 1. Testing of soil moisture control during cloudy weather.

\begin{tabular}{ccccc}
\hline Time & Moisture & Pump Status & SIM8266 & Ambient Temperature \\
\hline 07:00:00 & $63 \%$ & OFF & Send & $27^{\circ} \mathrm{C}$ \\
09:00:00 & $49 \%$ & ON & Send & $27^{\circ} \mathrm{C}$ \\
11:00:00 & $69 \%$ & OFF & Send & $29^{\circ} \mathrm{C}$ \\
13:00:00 & $75 \%$ & OFF & Send & $29^{\circ} \mathrm{C}$ \\
15:00:00 & $68 \%$ & OFF & Send & $28^{\circ} \mathrm{C}$ \\
17:00:00 & $68 \%$ & OFF & Send & $27^{\circ} \mathrm{C}$ \\
\hline Average & $\mathbf{8 6 \%}$ & & & \\
\hline
\end{tabular}


Table 2. Testing of room temperature control in cloudy weather.

\begin{tabular}{ccccc}
\hline Time & Temperature room & Fan Status & SIM8266 & Ambient Temperature \\
\hline 07:00:00 & $28^{\circ} \mathrm{C}$ & OFF & Send & $27^{\circ} \mathrm{C}$ \\
09:00:00 & $28^{\circ} \mathrm{C}$ & OFF & Send & $27^{\circ} \mathrm{C}$ \\
$11: 00: 00$ & $28^{\circ} \mathrm{C}$ & OFF & Send & $29^{\circ} \mathrm{C}$ \\
$13: 00: 00$ & $30^{\circ} \mathrm{C}$ & OFF & Send & $29^{\circ} \mathrm{C}$ \\
$15: 00: 00$ & $30^{\circ} \mathrm{C}$ & OFF & Send & $28^{\circ} \mathrm{C}$ \\
$17: 00: 00$ & $29^{\circ} \mathrm{C}$ & OFF & Send & $27^{\circ} \mathrm{C}$ \\
\hline Average & $\mathbf{2 8} \mathrm{C}$ & & & \\
\hline
\end{tabular}

\section{3-4- Watering and Temperature Control Testing During Rainy Weather}

Tables 3 and 4 below show the results of tests that were carried in October 2020, during the rainy season. It can be seen that the initial value of the percentage of soil moisture during rainy weather was $80 \%$ and the value of room temperature was $26^{\circ} \mathrm{C}$.

Table 3. Testing of soil moisture control in rainy weather.

\begin{tabular}{ccccc}
\hline Time & Moisture & Pump Status & SIM8266 & Ambient Temperature \\
\hline 07:00:00 & $80 \%$ & OFF & Send & $25^{\circ} \mathrm{C}$ \\
09:00:00 & $80 \%$ & OFF & Send & $25^{\circ} \mathrm{C}$ \\
11:00:00 & $85 \%$ & OFF & Send & $26^{\circ} \mathrm{C}$ \\
13:00:00 & $90 \%$ & OFF & Send & $25^{\circ} \mathrm{C}$ \\
15:00:00 & $80 \%$ & OFF & Send & $25^{\circ} \mathrm{C}$ \\
17:00:00 & $85 \%$ & OFF & Send & $25^{\circ} \mathrm{C}$ \\
\hline Average & $\mathbf{8 3 \%}$ & & & \\
\hline
\end{tabular}

Table 4. Testing of room temperature control in rainy weather.

\begin{tabular}{ccccc}
\hline Time & Temperature room & Fan Status & SIM8266 & Ambient Temperature \\
\hline 07:00:00 & $26^{\circ} \mathrm{C}$ & OFF & Send & $25^{\circ} \mathrm{C}$ \\
09:00:00 & $26^{\circ} \mathrm{C}$ & OFF & Send & $25^{\circ} \mathrm{C}$ \\
$11: 00: 00$ & $27^{\circ} \mathrm{C}$ & OFF & Send & $26^{\circ} \mathrm{C}$ \\
13:00:00 & $26^{\circ} \mathrm{C}$ & OFF & Send & $25^{\circ} \mathrm{C}$ \\
$15: 00: 00$ & $27^{\circ} \mathrm{C}$ & OFF & Send & $25^{\circ} \mathrm{C}$ \\
17:00:00 & $27^{\circ} \mathrm{C}$ & $\mathrm{OFF}$ & Send & $25^{\circ} \mathrm{C}$ \\
\hline Average & $\mathbf{2 6} \mathrm{C}$ & & & \\
\hline
\end{tabular}

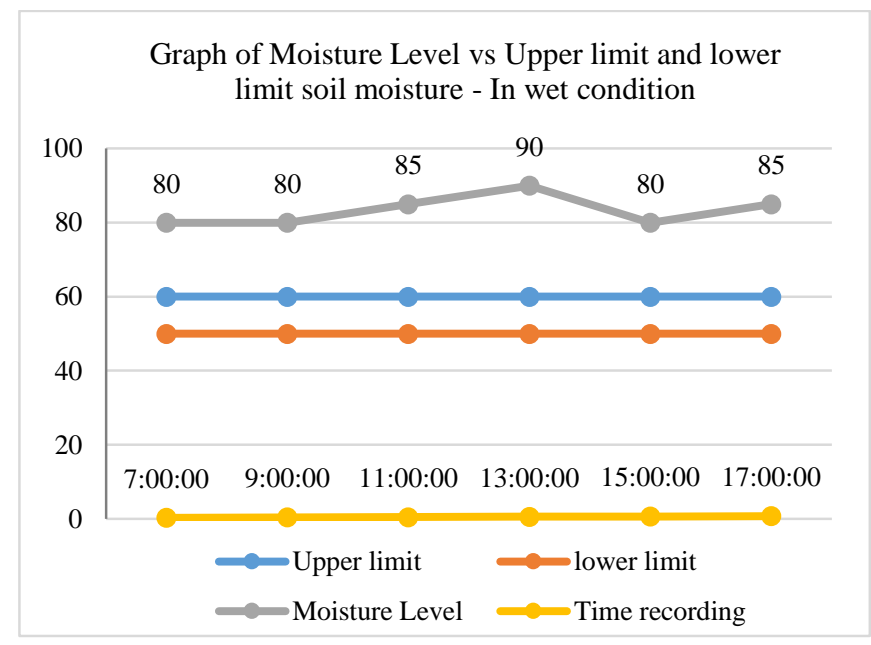

(a)

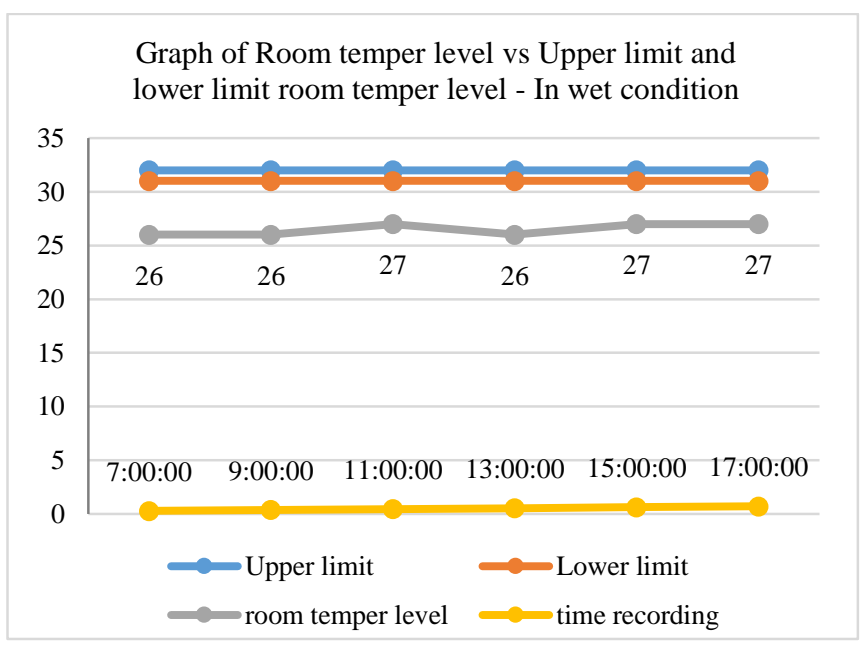

(b)

Figure 9. (a) Graph of Moisture Level; (b) Graph of Room temperature level. 
The test results on monitoring soil moisture in rainy weather conditions are shown in Figure 9. (a). It shows the system does not activate irrigation procedures to increase soil moisture because the system detects soil moisture which is still above the maximum limit of ideal soil moisture. The same results were also obtained from the greenhouse room temperature monitoring test as shown in Figure 9.(b) where the system also did not activate the temperature reduction procedure because the temperature system monitored was still below the minimum ideal temperature for onion plants. From the results of the tests that have been carried out, it can be concluded that during rainy weather the tools and systems capture soil moisture above $80 \%$ the DHT 11 sensor captures an average value of $26^{\circ} \mathrm{C}$.

\section{3-5- Watering and Temperature Control Testing During Hot Weather}

Tables 5 and 6 below show the results of tests carried out in April 2021. It can be seen that the initial value of the percentage of soil moisture during hot weather is $30 \%$ and the value of room temperature during hot weather is $33^{\circ} \mathrm{C}$ The test results on monitoring soil moisture in hot weather conditions are shown in Figure 10. (a), showing a fairly low soil moisture value of $30 \%$ so that the soil moisture mechanism is activated to obtain soil moisture conditions in accordance with the ideal limits as have been determined. While Figure 10. (b) shows similar results in the temperature monitoring test where the room temperature shows a fairly high-temperature value, which is above $32^{\circ} \mathrm{C}$ so that the air conditioning mechanism is activated to reduce the temperature in order to reach the ideal temperature value, which is between $31-32^{\circ} \mathrm{C}$.

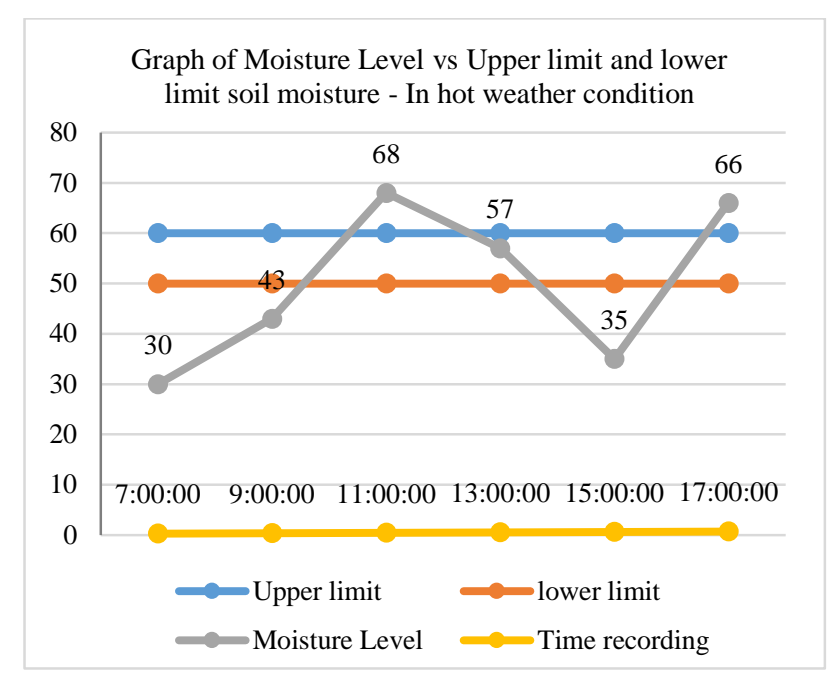

(a)

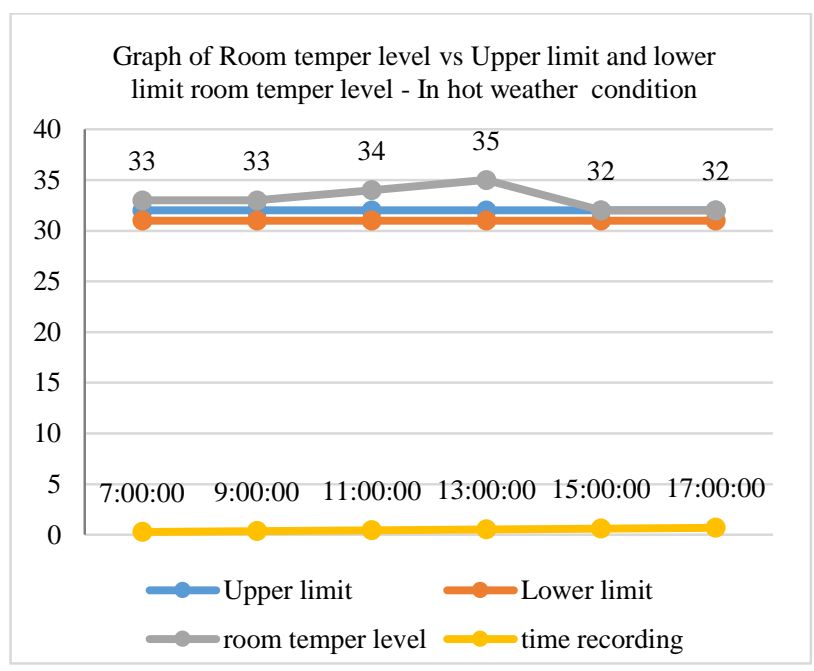

(b)

Figure 10. (a) Graph of Moisture Level; (b) Graph of Room temperature level.

Table 5. Testing of soil moisture control in hot weather.

\begin{tabular}{ccccc}
\hline Time & Moisture & Pump Status & SIM8266 & $\begin{array}{c}\text { Ambient } \\
\text { Temperature }\end{array}$ \\
\hline 07:00:00 & $30 \%$ & ON & Send & $28^{\circ} \mathrm{C}$ \\
09:00:00 & $43 \%$ & ON & Send & $36^{\circ} \mathrm{C}$ \\
11:00:00 & $68 \%$ & OFF & Send & $40^{\circ} \mathrm{C}$ \\
13:00:00 & $57 \%$ & OFF & Send & $45^{\circ} \mathrm{C}$ \\
15:00:00 & $35 \%$ & ON & Send & $38^{\circ} \mathrm{C}$ \\
17:00:00 & $66 \%$ & OFF & Send & $25^{\circ} \mathrm{C}$ \\
\hline Average & $50 \%$ & & & \\
\hline
\end{tabular}

Table 6. Testing of room temperature control in hot weather.

\begin{tabular}{ccccc}
\hline Time & $\begin{array}{c}\text { Temperature } \\
\text { room }\end{array}$ & Fan Status & SIM8266 & $\begin{array}{c}\text { Ambient } \\
\text { Temperature }\end{array}$ \\
\hline 07:00:00 & $33^{\circ} \mathrm{C}$ & ON & Send & $28^{\circ} \mathrm{C}$ \\
09:00:00 & $33^{\circ} \mathrm{C}$ & ON & Send & $36^{\circ} \mathrm{C}$ \\
11:00:00 & $34^{\circ} \mathrm{C}$ & ON & Send & $40^{\circ} \mathrm{C}$ \\
$13: 00: 00$ & $35^{\circ} \mathrm{C}$ & ON & Send & $45^{\circ} \mathrm{C}$ \\
15:00:00 & $32^{\circ} \mathrm{C}$ & OFF & Send & $38^{\circ} \mathrm{C}$ \\
17:00:00 & $32^{\circ} \mathrm{C}$ & OFF & Send & $25^{\circ} \mathrm{C}$ \\
\hline Average & $33^{\circ} \mathrm{C}$ & & & \\
\hline
\end{tabular}


Tests that have been carried out show that the process of reading the soil moisture on the planting soil by the sensor works well in any weather condition, and the process of sending data from Arduino to the database successfully functions and works according to the system and process of reading the DHT 11 sensor at a temperature the planting room, whether cloudy, rainy or hot, can run well. Similarly, the process of sending data from the Arduino to the database successfully functions and works according to the system. In soil moisture testing, it is known that there is a significant influence of weather conditions on the soil moisture conditions even as tested in the greenhouse, whereas the soil moisture in the greenhouse tends to follow the surrounding weather. If the test is carried out when the weather is hot, the soil moisture conditions in the greenhouse will be lower, conversely, tests during cloudy or rainy weather conditions show a high level of soil moisture. Similar conditions also occur in the measurements in the greenhouse room temperature monitoring tests $[20,21]$. Tests carried out during the hot weather show higher temperature values, whereas during rainy and cloudy weathers, the greenhouse's room temperature conditions are lower than the lowest limit of the ideal temperature for planting onions.

The findings related to the influence of weather applicable to our test indicate that the prototype greenhouse has a low level of isolation from the outside environment, so that the weather conditions in the surrounding environment still greatly affect the soil moisture and the greenhouse room temperature conditions. Thus the monitoring system that has been built has not been able to measure every detail of the impact of changes that occur in plants, due to the influence of weather factors external to the greenhouse. Based on these findings, it is necessary to study the design of the prototype greenhouse in order to increase the ability of the greenhouse to isolate its interior from weather influences from the surrounding environment. In addition, it is necessary to apply additional procedures in the form of a mechanism for reducing soil moisture or increasing the temperature of the greenhouse to overcome the condition of the greenhouse temperature being too low or the moisture being too high, especially during the rainy season. However, the system created has been able to work in accordance with the needs analysis in monitoring the growth of onion plants.

\section{4- Conclusion}

Based on the research and testing objectives that have been produced, it can be concluded that the prototype for monitoring the growth of onion plants using the NodeMCU ESP8266 is able to work well in controlling and responding to changes in soil moisture and air temperature in the prototype greenhouse that has been made based on the analysis of the growing needs of onion plants. The data results indicate that during cloudy weather, the tool and system record a soil moisture level above $60 \%$ and an average temperature of $28{ }^{\circ} \mathrm{C}$, during rainy weather, a soil moisture level above $80 \%$ and an average temperature is of $26^{\circ} \mathrm{C}$, while in hot weather, a soil moisture level below $50 \%$ and an average temperature of $33^{\circ} \mathrm{C}$. This research needs to be developed in a much larger application of different growing media for onion cultivation. Testing the prototype carried out in three different environmental conditions, namely cloudy, rainy and hot, to represent the tropical climates, resulted in the finding that the test environment has a significant influence on the environmental engineering of the greenhouse. This indicates the need for a design analysis on the prototype greenhouse, which should minimize the intervention of the external environment on the development of the onion growth environment. The use of drying/heating engineering also needs to be considered to be applied to the future prototype greenhouse design to anticipate conditions of low temperatures and excessively high soil moisture that might negatively affect onion cultivation. The results of this study have a great impact on local farmers, namely being able to understand the composition of the best climate for the growth of onions and educating farmers to be able to use technology in agriculture.

\section{5- Declarations}

\section{5-1-Author Contributions}

Conceptualization, I.H.W., Y.M. and R.R.; methodology, I.H.W., Y.M., R.R. and S.S.; software, I.H.W., S.S. and R.R.; validation, R.R. and S.S.; formal analysis, I.H.W., Y.M. and R.R.; investigation, S.S. and R.R.; resources, S.S. and R.R; data curation, H.H., S.S. and R.R.; writing — original draft preparation, H.H. S.S. and R.R.; writing-review and editing, H.H. and R.R.; supervision, H.H.; funding acquisition, H.H., R.R. and S.S. All authors have read and agreed to the published version of the manuscript.

\section{5-2-Data Availability Statement}

The data presented in this study are available in article.

\section{5-3-Funding}

The authors received no financial support for the research, authorship, and/or publication of this article.

\section{5-4-Acknowledgements}

The authors would like to thank the Agro-Engineering team who have completed this research, and also to Selamet Iriyanto, a final year student of Informatics Engineering, Musamus University, Merauke, Indonesia who has assisted in the creation and testing of the system of this research.. 


\section{5-5- Conflicts of Interest}

The authors declare that there is no conflict of interests regarding the publication of this manuscript. In addition, the ethical issues, including plagiarism, informed consent, misconduct, data fabrication and/or falsification, double publication and/or submission, and redundancies have been completely observed by the authors.

\section{6- References}

[1] Doloksaribu, A., H. Ismanto, and D. S. Susanti, "Webgis Model of Agricultural Land Management Using a Remote Sensing Technique in Merauke Regency of Papua.” International Journal of Innovative Science, Engineering \& Technology 04, no. 10 (October 2017): 39-45.

[2] Ismanto, Heru, Abner Doloksaribu, Diana Sri Susanti, and Dina Fitri Septarini. "The Accuracy of Remote Sensing Image Interprepation On Changes In Land Use Suitability In Merauke Regency Papua.” International Journal of Engineering Trends and Technology 68, no. 10 (October 25, 2020): 42-47. doi:10.14445/22315381/ijett-v68i10p207.

[3] Letsoin, S. M. A., D. Herak, F. Rahmawan, and R. C. Purwestri, "Land cover changes from 1990 to 2019 in Papua, Indonesia: Results of the remote sensing imagery.” Sustainability 12, no. 16 (August 2020): 01-18. doi:1010.3390/su12166623.

[4] Obidzinski, K., I Takahashi, A. Dermawan, H. Komarudin, and A. Andrianto, "Can large scale land acquisition for agrodevelopment in Indonesia be managed sustainably?." Land Use Policy 30, no. 01 (January 2013): 952-956. doi:10.1016/j.landusepol.2012.06.018.

[5] Ito, T., N. F. Rachman and L. A. Savitri, "Power to make land dispossession acceptable: a policy discourse analysis of the Merauke Integrated Food and Energy Estate (MIFEE), Papua, Indonesia.” The Journal of Peasant Studies 41, no. 01 (30 January 2014): 29-50. doi: 10.1080/03066150.2013.873029.

[6] McDonnell, John E. “The Merauke Integrated Food and Energy Estate (MIFEE): An Ecologically Induced Genocide of the Malind Anim.” Journal of Genocide Research 23, no. 2 (July 31, 2020): 257-278. doi:10.1080/14623528.2020.1799593.

[7] Statistics of Merauke, "Merauke Regency in Figures.” (February 26, 2021). Available online: https://meraukekab.bps.go.id/publication/2021/02/26/97ca4325f867c3604c247b8c/kabupaten-merauke-dalam-angka2021.html. (accessed on May 2021).

[8] Kelyaum, Laurentius Kelvin Setiawan, David Oscar Simatupang, and Maria Maghdalena Diana Widiastuti. "Kelayakan Usahatani Bawang Merah Di Distrik Tanah Miring.” Musamus Journal of Agribusiness 1, no. 1 (October 25, 2018): 16-22. doi:10.35724/mujagri.v1i1.1299.

[9] Wahyuni, S, J Hestina, I A Setiajie, and E Suryani. "Enhancing Red Onion Agribusiness Development: e-Planting Calendar and Production Allocation." IOP Conference Series: Earth and Environmental Science 653, no. 1 (February 1, 2021 ): 012006. doi:10.1088/1755-1315/653/1/012006.

[10] Wang, Chin - Kun. "Health Benefits of Onion Bioactives on Hypercholesterolemia, Cardiovascular Diseases, and Bone Mineral Density.” Food Frontiers 1, no. 2 (April 29, 2020): 107 - 108. doi:10.1002/fft2.18.

[11] Sravani, V, SN Saravaiya, BN Patel, HN Chhatrola, Himani B Patel, and JM Vashi. "Response of Plant Bioregulators on Growth Parameters and Plant Growth Analysis of Onion (Allium Cepa L.).” International Journal of Chemical Studies 8, no. 3 (May 1, 2020): 1312-1316. doi:10.22271/chemi.2020.v8.i3r.9380.

[12] Sriwantoko, S., E. Syam'un, F. Ulfa, "Growth of red onion plant (Allium ascalonicum L.) In an application by phosphate solubilizing microbes and goat dung compost." Advances in Environmental Biology 14, no. 07 (July 2020): 23-20. doi:10.22587/aeb.2020.14.7.4.

[13] Alfiani, A, F Haring, and E Syam'un. "Growth and Production of Red Onion (Allium Ascalonicum L.) with the Application of Monosodium Glutamate and Endophytic Fungi.” Journal of Physics: Conference Series 1899, no. 1 (May 1, 2021 ): 012001. doi:10.1088/1742-6596/1899/1/012001.

[14] Gupta, S., W. A. Stirk, L. Plackova, M. G. Kulkarni, K. Dolezal and J. V. Staden, "Interactive effects of plant growth-promoting rhizobacteria and a seaweed extract on the growth and physiology of Allium cepa L. (onion)." Journal of Plant Physiology 262, no. 153437 (July 2021): 01-11. doi:10.1016/j.jplph.2021.153437.

[15] Podder, A. K., A. A. Bukhari, S. Islam, S. Mia, M. A. Mohammed, N. M. Kumar, K. Cengiz, and K. H.Abdulkareem, "IoT based smart agrotech system for verification of Urban farming parameters." Microprocessors and Microsystems 82, no. 104025 (April 2021): 01-10. doi:10.1016/j.micpro.2021.104025.

[16] Ezirim, O. N., Okpoechi, C.U. "Community-driven Development Strategy for Sustainable Infrastructure" Journal of Human, Earth, and Future 01, no 2 (June 2020): 48-59. doi:10.28991/HEF-2020-01-02-01.

[17] Shamshiri, R. R., I. Bojic, E. V. Henten, S. K. Balasundram, V. Dworak, M. Sultan and C. Weltzien, "Model-based evaluation of greenhouse microclimate using IoT-Sensor data fusion for energy efficient crop production." Journal of Cleaner Production 263, no. 121303 (August 2020): 01-17. doi:10.1016/j.jclepro.2020.121303. 
[18] Khoa, T. A., M. M. Man, T. Y. Nguyen, V. D. Nguyen, and N. H. Nam, "Smart agriculture using IoT multi-sensors: A novel watering management system." Journal of Sensor and Actuator Networks 08, no. 45 (August 2019): 01-22, doi: $10.3390 /$ jsan 8030045 .

[19] Sekaran, K., M. N. Meqdad, P. Kumar, S. rajan, and S. Kadry, "Smart agriculture management system using internet of things" TELKOMNIKA (Telecommunication Computing Electronics and Control) 18, no. 03 (June 2020): 1275-1284. doi:10.12928/TELKOMNIKA.v18i3.14029.

[20] Rahmat, R F, S Adnan, R Anugrahwaty, E P S Alami, and B Siregar. "Red Onion Growth Monitoring System in Hydroponics Environment.” Journal of Physics: Conference Series 1235 (June 2019): 012117. doi:10.1088/1742-6596/1235/1/012117.

[21] Kaburuan, E. R., R. Jayadi, and Harisno, "A design of IoT-based monitoring system for intelligence indoor micro-climate horticulture farming in Indonesia" 4th International Conference on Computer Science and Computational Intelligence 2019 (ICCSCI) (September 2019). doi;10.1016/j.procs.2019.09.001.

[22] Khan, Zahid, Muhammad Zahid Khan, Sikandar Ali, Irshad Ahmed Abbasi, Haseeb Ur Rahman, Umar Zeb, Hizbullah Khattak, and Jiwei Huang. "Internet of Things-Based Smart Farming Monitoring System for Bolting Reduction in Onion Farms." Edited by Imran Sarwar Bajwa. Scientific Programming 2021 (July 23, 2021): 1-15. doi:10.1155/2021/7101983.

[23] Kapoulas, N., A. Koukounaras, and Z. S. Ilic, "Nutritional quality of lettuce and onion as companion plants from organic and conventional production in north Greece." Scientia Horticulturae 219, no. 01 (May 2017): 310-318. doi:10.1016/j.scienta.2017.03.027.

[24] Guirado-Clavijo, R., J. A. Sanchez-Molina, H. Wang, and F. Bienvenido, "Conceptual Data Model for IoT in a Chain-Integrated Greenhouse Production: Case of the Tomato Production in Almeria (Spain).” IFAC-PapersOnline 51, no. 17 (2018): $102-107$. doi:10.1016/j.ifacol.2018.08.069.

[25] Kumar, A., V. Singh, S. Kumar, S. P. Jaiswal, and V. S. Bhadoria, "IoT enabled system to monitor and control greenhouse." Materialstoday: Proceedings (December 2020): 01-05. doi:10.1016/j.matpr.2020.11.040.

[26] Azhar, F. C., B. Irawan, and R. E. Saputra, "Controlling and monitoring ornamental plants care remotely using android application." 2017 IEEE Asia Pacific Conference on Wireless and Mobile (APWiMob) (November 2017). doi:10.1109/APWiMob.2017.8283993.

[27] Santiago Jr, C. S., J. A. V. Murray, L. Z. D. Pieza, and S. Dizon, "Plant Monitoring System for Vegetable Growers." International Journal of Recent Technology and Engineering (IJRTE) 08, no. 06 (March 2020): 3097-3100. doi:10.35940/ijrte.f8393.038620.

[28] Arduino.cc, “Arduino official Store.” (2021). Available online https://www.arduino.cc/en/Guide/Introduction (accessed on July 29, 2021).

[29] Hariono, T., and M. C. Putra, "Data Acquisition for Monitoring IoT-Based Hydroponic Automation System Using ESP8266." NEWTON: Networking and Information Technology 01, no. 01 (June 2021): 01-07.

[30] Ahmed, I. A. O., and M. E. E. Daleel. "Automated Use Case Diagram Generation with Non-functional Requirements using Neural Network.” International Journal of Applied Information Systems (IJAIS) 12, no. 34 (October 2020): 1-4.

[31] Arifin, Mohammad Nazir, and Daniel Siahaan. "Structural and Semantic Similarity Measurement of UML Use Case Diagram." Lontar Komputer : Jurnal Ilmiah Teknologi Informasi 11, no. 2 (July 13, 2020): 88. doi:10.24843/lkjiti.2020.v11.i02.p03. 